\title{
REPORT OF THE WORKING GROUP ON ABUNDANCE ESTIMATES
}

\author{
Enrique A. Crespo, Eduardo R. Secchi, Luciano Dalla Rosa, Paul G. Kinas, Daniel Danilewicz and Pablo Bordino
}

\section{Background}

The franciscana dolphin, Pontoporia blainvillei, is endemic to the western South Atlantic Ocean and has been considered the most threatened small cetacean in this region. For this reason, abundance estimates were recognised and recommended as a research priority long time ago, first at the Workshop for the River Dolphins carried out at Wuhan in 1986 (Perrin et al., 1989) and also at the following workshops carried out in Argentina and Brazil (Crespo, 1992; Pinedo, 1997). Population size estimates were needed to provide baseline information and allow a comparison with mortality rate estimates for different areas of the franciscana's range, especially as some of those mortality rate estimates were suspected to be unsustainable. The delay in achieving such objective was in part a result of a lack of human resources in the region with the appropriate methodological training in both field work and data analysis for abundance estimation, as well as due to financial constraints. The opportunity for a first survey was given in March 1996.

\section{Previous work}

Although estimates of relative density of franciscana have been obtained for Baia Anegada, Argentina (Bordino and Tausend, 1998) and for Baia de Babitonga, Brazil (Marta Cremer, personal communication during the Fourth Workshop), the only preliminary estimate of abundance for a putative franciscana stock inhabiting the coasts of Rio Grande do Sul State (southern Brazil) and Uruguay was obtained from surveys carried out in March 1996. Aerial surveys were conducted in the Rio Grande do Sul State coast (Secchi et al., 2001).

Thirty-four franciscanas (29 groups) were recorded, leading to a mean density of 0.657 individuals $/ \mathrm{km}^{2}$ (95\% CI: 0.516 to 0.836$)$ for the study area $\left(435 \mathrm{~km}^{2}\right)$ after applying a correction factor that considers the probability of missing submerged dolphins. This corresponds to an estimated population of 286 franciscanas (95\% CI: 225 to 364) within the survey region. In an attempt to analyse mortality estimates in gillnet fisheries with respect to abundance estimates, density estimates for the area surveyed were assumed to be the same throughout the entire stock's range, which resulted in a population size estimate of 42,078 franciscanas (95\% CI: 33,047 to 53,542). It is important to point out that these results need to be used with caution as they are based on surveys carried out over a small fraction of the coastline, which corresponds to only $0.7 \%$ of the possible range of the stock $\left(\right.$ ca $\left.64,045 \mathrm{~km}^{2}\right)$. Furthermore, there is limited information about distributional patterns of this species. However, these estimates might be used to set the order of magnitude of the population for quantitative simulations in demographic studies. This result is the first attempt to estimate franciscana abundance with aerial surveys. Further surveys covering a larger area are necessary to obtain more reliable abundance estimates for the stock (for further details, see Secchi et al., 2001).

\section{Recommendations for estimates of abundance}

Two types of platforms are commonly used for abundance estimation of cetaceans at sea: high wing twin-engine aircrafts, and sail or engine powered vessels. Comments on both are given below, as well as on sample design and other considerations.

\section{Twin-engine high wing aircrafts}

In the case of twin-engine high wing aircrafts, a flying speed of 80 to 90 knots and a flying altitude of 500 to 600 feet are recommended. An increase in flying speed of the aircraft or an increase in flying altitude could lead to a large number of sightings missed, and hence to underestimates of density. The plane allows a large area to be surveyed at lower costs (UNEP/CMS, 2000).

Special aircrafts holding bubble windows allow a vertical view when observing at sea, and for this reason are preferred over aircrafts with traditional windows. However, if such apparatus is lacking, the effects of the blind zone immediately beneath the plane must be taken into account when estimating detection probabilities ( $c f$ Buckland et al., 2001, p. 280). It is strongly recommended that the use of single-engine aircrafts be avoided when surveying in the open sea, for safety reasons.

\section{Vessel platforms}

A second option would be to use fast vessels such as coast guard boats, at a speed of around 8 knots, with high observation platforms. In this case the costs would be higher and the area surveyed smaller than if an aircraft was used. The area surveyed by a vessel in 5 hours is a quarter of that surveyed by aircraft, increasing the mistakes made by the observers due to fatigue. Nevertheless, engine noise is probably responsible for franciscana avoidance of boats as reported in Pinedo et al. (1989) and Secchi et al. (2001). In southern Brazil, no franciscana sightings have been reported from over 150 cruises which carried experienced observers onboard fishing vessels in coastal waters of northern Rio Grande do Sul State, despite the fact that this area contains spots of high incidental captures 
of the species (GEMARS ${ }^{1}$, pers. observ.). It seems obvious that, for some areas, surveys carried out from motor powered boats would affect the distribution of sightings, due to the species' tendency to avoid powered-engine boats. Engine noise is thus likely to increase the diving period of franciscana. In addition, it is feared that, as the group size of franciscanas is so small, many sightings could be missed from vessel platforms, leading to underestimates of density. The use of 25 power binoculars ("big eyes") for the observer to search on the trackline is recommended, in an attempt to minimise the number of individuals on the trackline that are not seen. One last option would be to use platforms fixed to slower vessels (sail or motor boats), although this is not recommended. They could work under special conditions such as for migration studies or for abundance estimates based on passive acoustic methods. In the first case, platforms could be placed perpendicularly to the direction of migration. When sound is used to estimate abundance, the use of hydrophones should be discarded because they are not suitable for estimating abundance. It is not known whether "signature whistles" or other type of sounds (except those of echolocation) occur among franciscanas. Nevertheless, this technology is too expensive to be used in these studies (Von Fersen et al., 2000), even thought some controversy exists.

\section{Sampling design}

The survey should be designed according to the conditions of the area and to previous information on the presence of the species, distribution of prey species and location of isobaths. A zigzag pattern or a set of perpendicular or diagonal transects to the coastline are especially useful for open sea areas ( $c f$ Buckland et al., 2001, p. 232). For small bays or gulfs, parallel lines covering the whole area are also suitable. It is essential that observers be well trained.

\section{Sea state}

In all previous cases the state of the sea should be lower than 3 in the Beaufort scale. Due to the species characteristics (e.g. brief breathing without conspicuous splashes, small group size, small body size and non-descript colour), working in Beaufort 3 or over decreases sighting probability, and missing sightings on the trackline leads to an underestimation of density.

\section{Data analysis}

The philosophy of abundance estimation of cetaceans falls well within the distance sampling methodology, in which the probability of sighting objects is equal to 1 on the transect line and decays monotonically with a given function perpendicularly to the transect line. The reader is recommended to be familiar with the related literature (e.g. Buckland et al., 1993; Buckland et al., 2001; Laake et al., 1996).

\section{References}

Bordino, P. and Tausend, P. (1998) Avistabilidad y estimación preliminar de densidad del delfin franciscana Pontoporia blainvillei en Bahia Anegada, Argentina. Page 28 in Abstracts, VIII Reunião de Trabalho de Especialistas em Mamíferos Aquáticos da América do Sul. 25-29 October, Olinda.

Buckland, S.T., Anderson, D.R., Burnham, K.P. and Laake, J.L. (1993) Distance Sampling: Estimating abundance of biological populations. Chapman \& Hall, London.

Buckland, S.T., Anderson, D.R., Burnham, K.P., Laake, J.L., Borchers, D.L. and Thomas, L. (2001) Introduction to Distance Sampling: Estimating abundance of biological populations. Oxford University Press, Oxford.

Crespo, E.A. (1992) Report of the Workshop. I Workshop for the coordination of research and conservation of the franciscana dolphin (Pontoporia blainvillei) in the southwestern Atlantic. 2528 September 1992, Buenos Aires, Argentina. Presented to the United Nations Environment Programme, Nairobi, (Unpublished). 30pp.

Laake, J.L., Buckland, S.T., Anderson, D.R. and Burnham, K.P. (1996) DISTANCE User's Guide V 2.2. Colorado Cooperative Fishery \& Wildlife Research Unit. Colorado State University, Fort Collins, Colorado. 82pp.

Perrin, W.F. and Brownell Jr., R.L. (1989) Report of the Workshop on Conservation and Biology of the Platanistoid Dolphins. Pages 1-22 in Perrin, W.F., Brownell, R.L., Kaiya, Z. and Jiankang, L. (Eds) Biology and Conservation of the River Dolphins. Occas. pap. IUCN SSC 3. Gland.

Pinedo, M.C. (1997) Relatório do 2 Encontro. Pages 1-12 in Pinedo, M.C. and Barreto, A. (Eds) Anais do $2^{\circ}$ Encontro sobre Coordenação de Pesquisa e Manejo da Franciscana. Ed. FURG, Rio Grande.

Secchi, E.R., Ott, P.H., Crespo, E.A., Kinas, P.G., Pedraza, S.N. and Bordino, P. (2001) A first estimate of franciscana (Pontoporia blainvillei) abundance off southern Brazil. Journal of Cetacean Research and Management 3: 95-100.

UNEP/CMS (Ed.) (2000). Report of the Third Workshop for Coordinated Research and Conservation of the Franciscana Dolphin (Pontoporia blainvillei) in the Soutwestern Atlantic. UNEP/CMS, Bonn.

Von Fersen, L, Kamminga, C. and Seidl, A. (2000) Estudios preliminares sobre el comportamiento de un ejemplar de franciscana (Pontoporia blainvillei) en Mundo Marino, Argentina. Pages 30-33 in UNEP/CMS (Ed.) Report of the Third Workshop for Coordinated Research and Conservation of the Franciscana Dolphin (Pontoporia blainvillei) in the Soutwestern Atlantic. UNEP/CMS, Bonn. 